\title{
Diversity Analysis and Physico-Morphlogical Characteritics of Indigenous Germplasm of Lablab Bean
}

\author{
Ram Bahadur $\mathrm{KC}^{1^{*}}$, Bal Krishna Joshi ${ }^{2}$ and Surya Prasad Dahal ${ }^{3}$ \\ ${ }^{1}$ Nepal Agricultural Research Council, Singhdurbar Plaza, Kathmandu. \\ ${ }^{2}$ National Agriculture Genetic Resources Center, Khumaktar \\ ${ }^{3}$ Horticulture Research Station, Pokhara \\ *Correspondence: rbkc05@gmail.com
}

Received February 2016; Revised October 2016; Accepted November 2016

Scientific Editors: Jiban Shrestha, Dhruba Bhattarai

Copyright $@ 2016$ NARC. Permits unrestricted use, distribution and reproduction in any medium provided the original work is properly cited

\begin{abstract}
ABSTARCT
Germplasm characterization is an important component of crop breeding program. In characterizing indigenous beans lablab which is used for vegetables as well pulses in Nepal. Twenty three lablab beans germplasm were evaluated for different qualitative and quantitivephysicomorphological charecteristicsfor two years during 2011 and 2012 at Horticulture Research Station Malepatan, Pokhara. The germplasm showed considerable variations inmost of the qualitative and quantitative traits. Leaf size, vine color, flower color, podcolor, pod shape, pod type and seed color varied among the genotypes. Variation was also observed in yield attributing characters eg, pod length and width, 10 fresh pod weight, seeds per pod and 100-seed weight. Days to 50\% flowering ranged from 81 to 130 days indicating the presence of early varieties. Fresh pod weight of 10 pods was ranged from $45.0 \mathrm{~g}$ to $162.5 \mathrm{~g}$.Multivariate analysis indicated four groups in these genotypes, among with ML-02 and ML-10 were distinct in comparioson with other genotypes. Simple selection may be considered to develop high yielding, early type varieties from these gentopypes.
\end{abstract}

Key words: Lablab bean, qualitative, quantitative, variation

\section{सारांश}

सन २०११ र २०१२ मा हिंउदे सिमीका २३ वटा जर्मप्लाज्महरुलाई तिनको संरचनागत गुणात्मक र मात्रात्मक भिन्नता छुछटाउने मूल्याकनका परिणहरु संचालन गरिएको थियो । पातको आकार, लहराको (डांठ) रड़, फूलको रड़, कोसाको रझ़, कोसाको आकार र किसिम, बीउको रड़ आदिमा ती मूल्याकन गरिएका जर्मप्लाज्महरुमा प्रशस्त भिन्नता रहेको पाइयो । उत्पादनशील गुणहरु जस्तै $\% ० \%$ फूल फुल्न लाग्ने दिन, कोशाको लम्बाइ चौडाइ, हरियो कोशा तयार हुन लाग्ने दिन, दसवटा कोसाको तौल र १०० दाना बीउको तौल आदीमा पनि भिन्नता पाइयो । ४०\% फूल फुल्न लाग्ने अवधि द१ दिन देखि १३० दिन सम्म लाग्नाले छिटै कोसा तयार हुने सम्भावना देखियो। ताजा हरिया कोसाको तौल पनि ४४ ग्राम देखि १६२. प्राम सम्म फरक पाइएकोले बढी उत्पादनदिने जातहरु पन छ.नौट गर्न सकिने उक्तअध्ययनले औल्याएको छ,

\section{INTRODUCTION}

The lablab bean (LababpurpureusL.), also called field bean, Indian bean, Hyacinth bean or Dolichus bean is an old domesticated pulse and multipurpose cropfor human food, animal feed and cover crop (Chakravarti and Naravaneni 2006,Maass 2010). It is called Hiunde Simi,Tate Simi, Laphre Simi and Machhe in Nepal and some farmers cultivate perennially. This bean is a minor winter vegetable in Nepal and grown in most of districts of Mid Hill and Tarai areas. It is considered one of nutritious vegetable in green pod stage while pulse in the form of dry seeds (Chadha 2001). The foliage of the crop can be used as green feed, hay and silage.This crop can also grow well in alkaline and saline soil $\mathrm{pH}$ ranges up to 9.0 (Chadha 2001). The vine is grown at the roof top of the homested. This bean is easy to grow with limited inputs. Most of the farmer's households grow this bean having several landraces from Midhill to Tarai zone. Conservation of some landraces has been initiated by National Genebank of Nepal Agricultural Research Council (NARC), Khumaltar (Genebank 2014). However, information on diversity and characterisitcs of Nepalese lablab beans is scant.

Assessment of genetic diversity is important for crop improvement. Characterization is the preliminary works helps to support conservation and utilization effectively (Chakravarthi 2006, Genebank 2014). Lablab is one of the most diverse domesticated legume species with largest agro-morphological diversity in South Asia, even though orginated in Africa (Maass 2010). It is a tropical crop mainly grown in South Asia (specifically India, Nepal and Bangladesh), South East Asia and Africa. Considerable variations have been noticed in this bean in Bangladesh and India (Islam 2014, Rai et al 2010). Great range of variations exists in the plant and pod characters among the landraces grown in Nepal. They differs also by name eg Kerau Simi, Laphre Simi, Machhe Simi, etc. On the basis of physicomorpholoigical traits, landraces of this bean can be classified into two groups, namely, the 'bushy field cultivars' and 'twining pole garden cultivars'. Only pole type exists in Nepal which isgenerally grown for home consumption. Since, characterization and diversity assessment are necessary on lablab beans. Therefore, we aimed to collect lablab bean landracesfor diversity characterization based on physicomorpholoigical traits using multivariate analysis tools.

\section{MATERIALS AND METHODS}

A total of 23 indigenous germplasmof twining pole genotypes of lablab bean were collected including passport data (Table 1) from seven districts namely, Myagdi, Baglung, Parbat, Syangja, Gulmi, Kaski and Rupandehi in 2010 and 2011. To characterize and assess 
the diversity among these genotypesfield experiments were conducted inJune to February2011 and same months in 2012 at Agriculture Research Station,Malepatan, Pokhara. Soil type of the experimental plot was sandy loam with having soil pH 5.5 or less.

Unreplicated design was adopted for this study. The plot size was $2 \mathrm{~m}$ x $2 \mathrm{~m}$ accommodating four hills per plot. Four seeds per hill were planted initially. In each hill six kilogram of farm yard manure(FYM) was added.Inorganic fertilizers were applied @ 10 kgnitrogen $(\mathrm{N}), 25 \mathrm{~kg}$ phosphorus $(\mathrm{P})$ and $25 \mathrm{~kg}$ potassium (K) per ha as basal fertilizers. At knee height stage of seedlings, two seedlings per hills were maintained. First side dressing of $5 \mathrm{~kg} \mathrm{~N}$ was applied one month after seeding and; Second side dressing of $5 \mathrm{~kg} \mathrm{~N}$ was applied 60 days after seeding. Seedlings were supported by bamboo stick. Weeding and irrigation was done whenever necessary. The crop was protected from aphid by spraying Niconim (product of Neem) at the rate of five $\mathrm{ml} / \mathrm{L}$ of water at 15 days interval. Physicomorphological qualitative and quantitative traits were recorded each year from all four hills of each genotypefollowing the descrioptons of AVRDC (www.avrdc.org) and Sultana (2001).Quantative data were recorded from each hill and averaged over the plot each year. Mean value over the years were presented. These mean data were then subjected to cluster and principal component analysis as described by Joshi et al (2010) for genetic diversity analysis using Mintab software. Fresh pods of 15 genotypes were tested organoleptically providing to 15 different consumers (one genotype to each consumer) in 2011 and their views were recorded.

Table 1.Passport information of lablab bean genotypes used in the study

\begin{tabular}{|l|l|c|l|l|}
\hline Genotype & Local name & Altitude, $\mathbf{m}$ & Farmer (donor) name & Collection site \\
\hline ML-01 & Tate Simi/Lafre & 650 & JyotiDumre & Tulsi Bhayangja-5, Syangja \\
\hline ML-02 & Tate Simi & 650 & JyotiDumre & Tulsi Bhayangja-5, Syangja \\
\hline ML-03 & Hiunde Simi & 650 & GunakharDhakal & Tulsi Bhayangja-2, Syangja \\
\hline ML-04 & Hiunde Simi & 650 & GunakharDhakal & Tulsi Bhayangja-2, Jimuwa, Syangja \\
\hline ML-05 & Hiunde Simi & 1000 & BalBahadur Nepali & Khurkot, Parbat \\
\hline ML 07 & Machhe Simi & 800 & $\begin{array}{l}\text { Devi Prasad Bhusal } \\
\text { (Bermeli) }\end{array}$ & Devisthan-7, Parbat \\
\hline ML-08 & Machhe Simi & 950 & JagatBahadur GC & Narayansthan-2, Balewa, Baglung \\
\hline ML-09 & Hiunde Simi & 125 & Lekha KC & Shankarnagar-1, Rupendehi \\
\hline ML-10 & Hiunde Simi & 120 & Home BahadurRana & Kahariya-1, Tulsipur, Rupendehi \\
\hline ML-11 & Hiunde Simi & 1000 & Man bahadur KC & Singha-4, Tatopani, Myagdi \\
\hline ML-15 & Hiunde Simi & 875 & Hari GC & Durlungchok, Kusma, Parbat \\
\hline ML-16 & Hiunde Simi & 100 & DevBahadur Poon & Padsari-5, Rupendehi \\
\hline ML-17 & Hiunde Simi & 100 & DevBahadur Poon & Padsari-5, Rupendehi \\
\hline ML-18 & Hiunde Simi & 100 & DevBahadur Poon & Padsari-5, Rupendehi \\
\hline ML-19 & Hiunde Simi & 100 & Geru Poon & Padsari, Rupendehi \\
\hline ML-20 & Hiunde Simi & 850 & Geru Poon & Malepatan, Pokhara, Kaski \\
\hline ML-21 & Hiunde Simi & 1250 & Geru Poon & Gaidakot-3, Raja, Gulmi \\
\hline ML-22 & Hiunde Simi & 1250 & Geru Poon & Arkhala-6, Gulmi \\
\hline ML-23 & Hiunde Simi & 1250 & Geru Poon & Arkhala-6, Dandakharka, Gulmi \\
\hline ML-25 & Hiunde Simi & 1450 & SitaSubedi & Dhikurpokhari, Kaski \\
\hline ML-26 & Hiunde Simi & 950 & Lokmaya GC & Narayansthan, Balawa, Baglung \\
\hline ML-27 & Hiunde Simi & 1050 & KharpaniPulkoMukhkoGhar* & Sardikhola-9, Kaski \\
\hline ML-28 & Hiunde Simi & 650 & NildebBhattarai & Jagtradevi-9, Lalyang, Syangja \\
\hline
\end{tabular}

Note: $M=$ Malepatan, $L=$ Lablab bean (ARS2013). * Respondent did not give name of farmer and this is the term used to identify the house.

\section{RESULTS}

\section{Qualitative Characters}

The sizes of the leaves of each genotype were ovserved visually. Three different sizes of the leaves among 23 genotypes were noted. Fifteen genotypes had medium sized leaves whereas seven genotypes had small sized leaves and one genotype had relatively large sized leaves (Table 2).Chlorophyll content in the plant, expressed by the foliage color of the vegetative part did not have too much variation. Among the 23 genotypes, 17 (73.9\%) were observed green and six (26.15\%) were purple vine.Three types of flower color were observed. Flower color of $12(52.17 \%)$ was purple, 8 (34.78\%) white, and $3(13.04 \%)$ pink.

Pod color was of three different kinds: green, purple and white. There were 12 (52.17\%)genotypes with green colored pods, 7 (30.43\%) with purple and $4(17.39 \%)$ with white colored pods. Pod shapes were straight, slightly curved and curved pods (Table 2$)$. The numbers of genotypes having slightly curved shaped pods were 12(52.17\%),having straight pod shaped 10 (43.48\%), and pod with curved shaped 1 (4.35\%).There were $13(56.52 \%)$ genotypes with flat type pods and $10(43.48 \%)$ genotypes with round type pods.

According to seed coat color, genotypes were classified into five groups (Table 2). These were brown, black, white, black brown and gray brown. Among the 23 genotypes, 12 (52.17\%) had brown seed coat followed by 7 (30.43\%)genotypes with black coated seeds. Two genotypes had gray black and one brown black and one with white color seed coat. Considering the cooking quality, taste and over all performance of fresh pods, ML-09 was found best among the genotypes (Table 3). ML-09 was preferred by consumers due to small and bold pod with fiberless. It is also known as pea type bean. Other genotpypespreferred by consumers were ML-02, ML-04, ML-08, ML09, ML-10, ML-15, ML-18, ML-19, and ML-20. Five genoptypes, namely ML-02, ML-05, ML-08, ML-09 and ML-18 were found high yielders and they are recommended for further yield verification trial. 
Vol. 2:15-21, December 2016

DOI: http://dx.doi.org/10.3126/jnarc.v2i0.16116

Table 2. Qualitatitivephysio-morphological charecteristics of lablab beans germplasms

\begin{tabular}{|c|c|c|c|c|c|c|c|}
\hline Genotype & $\begin{array}{l}\text { Flower } \\
\text { color }\end{array}$ & $\begin{array}{l}\text { Pod } \\
\text { color }\end{array}$ & $\begin{array}{l}\text { Vine } \\
\text { color }\end{array}$ & Seed color & Leaf size & Pod form & Pod type \\
\hline ML-01 & Pink & Green & Green & Black & Medium & Slightly curved & Flat \\
\hline ML-02 & white & Green & Green & Brown & Medium & Straight & Flat, attractive \\
\hline ML-03 & White & Green & Green & Brown & Medium & Straight & Flat \\
\hline ML-04 & Purple & Purple & Purple & Brown & Medium & Slightly curved & Round \\
\hline ML-05 & Purple & Green & Green & Black & Medium & Slightly curved & Round \\
\hline ML 07 & Pink & Green & Green & Gray black & Medium & Slightly curved & Round \\
\hline ML-08 & Purple & Green & Green & Gray black & Medium & Slightly curved & Round, attractive \\
\hline ML-09 & Purple & Purple & Purple & Black & Small & Slightly Curved & Flat \\
\hline ML-10 & White & White & Purple & Brown & Small & Straight & Round \\
\hline ML-11 & Purple & Purple & Purple & Black & Medium & Semi curved & Round \\
\hline ML-15 & purple & Purple & Purple & Black & Medium & Slightly curved & Flat \\
\hline ML-16 & White & Green & Green & White & Medium & Straight & Flat \\
\hline ML-17 & White & Green & Green & Brown & Medium & Straight & Flat \\
\hline ML-18 & Purple & Green & Green & Brown & Small & Curved & Round \\
\hline ML-19 & Purple & Purple & Purple & Brown & Small & Slightly Curved & Round \\
\hline ML-20 & Purple & White & Green & Black & Medium & Curved & Flat \\
\hline ML-21 & White & Green & Green & Brown & Small & Slightly Curved & Flat \\
\hline ML-22 & Pink & Purple & Green & Brown & Large & Curved & Round \\
\hline ML-23 & Purple & White & Green & Brown & Medium & Straight & Flat \\
\hline ML-25 & Purple & Green & Green & Brown & Medium & Straight & Rou nd \\
\hline ML-26 & White & Green & Green & Brown & Medium & Straight & Flat \\
\hline ML-27 & Purple & White & Green & Black brown & small & straight & Flat \\
\hline ML-28 & Purple & Purple & Purple & Black & small & straight & Flat \\
\hline
\end{tabular}

Table 3. Consumers' views on the germplasm of pole type lablab beans

\begin{tabular}{|l|l|}
\hline Genotype & Consumer comments \\
\hline ML-01 & Tasty, soft, slightly fibrous, no presence of insects \\
\hline ML-02 & Tasty, soft and no insect found inside pod \\
\hline ML-03 & Ok, fibrous and presence of insects inside pod \\
\hline ML-04 & Tasty, soft, no insects found inside pod \\
\hline ML-05 & Tasty, little fiber, soft, presence of insects inside pod \\
\hline ML-07 & Ok, soft, slightly fibrous, presence of insects in small scale \\
\hline ML-08 & Tasty, soft, presence of insects in small scale \\
\hline ML-09 & Tasty, soft, presence of insects in small scale \\
\hline ML-10 & Tasty, soft, no presence of insects \\
\hline ML-11 & Tasty, soft, slightly fibrous, no presence of insects \\
\hline ML-15 & Tasty, soft, slightly fibrous, no presence of insects \\
\hline ML-16 & Tasty, soft, slightly fibrous, no presence of insects \\
\hline ML-17 & Tasty, soft, slightly fibrous, no presence of insects \\
\hline ML-18 & Tasty, soft, slightly fibrous, presence of insects in small scale \\
\hline ML-19 & Tasty, soft, slightly fibrous, presence of insects inside pod \\
\hline ML-20 & Tasty, soft, slightly fibrous, no presence of insects \\
\hline
\end{tabular}

\section{Quantitive Characters}

Wide range of variation (49 days difference)was observed in days to 50\% flowering among tested genotypes (Table 4). The genotypes ML-09 and ML-15 flowerd at 81 days and other early flowering genotypes were ML-22 (85.5 days), ML-27, and ML-28 (86.5 days). Based on the two years result, ML-02, ML-11, ML-19, ML-20 were flowered in 120 days, whereas ML-17 and ML-16 were observed extremely late flowering type which took 124 and 130 days to flowerrespectively.Variation was also observed in fresh pod maturity days for culinary purpose. The differencein pod maturity for days to first harvestwas44.5between early and late type genotypes. ML-15 took only 119 days for harvesting first fresh pods. Other early types were ML-22 (122 days), ML-27, ML-28 (124 days). Late types in pod maturity were ML-17, ML-19, ML-20 ML-23, ML-25, which took 164 days for harvesting fresh pods. ML-16 was extremely late maturing type which took 165.5 days for first fresh pod harvest.Pod length varied from 5.35 to $15.45 \mathrm{~cm}$ (Table 4). The longest pod was of ML-05 $(15.45 \mathrm{~cm})$, followed by ML-08 $(14.7 \mathrm{~cm})$ and ML-18 $(13.95 \mathrm{~cm})$. Whereas shortest pod length was recorded in ML-09 (5.35 $\mathrm{cm})$ followed by ML-22 $(6.45 \mathrm{~cm})$ and ML-10 $(6.5 \mathrm{~cm})$.Pod width ranged from 3.9 to $9.11 \mathrm{~cm}$. The widest pod was recorded in ML-02 $(9.11 \mathrm{~cm})$, followed by ML-28 $(6.5 \mathrm{~cm})$, ML-05 $(6.3 \mathrm{~cm})$, and ML-01 $(6.2 \mathrm{~cm})$ whereas, the shortest pod width was recorded in ML-19 $(3.9 \mathrm{~cm})$. 
Table 4. Quantitative physico-morphological charecteristics of lab lab beans characterized during 2011 and 2012

\begin{tabular}{|c|c|c|c|c|c|c|c|}
\hline Genotype & $\begin{array}{l}\text { Flowering } \\
\text { days }\end{array}$ & $\begin{array}{l}\text { Pod maturity days } \\
\text { for first harvest }\end{array}$ & Pod length, cm & $\begin{array}{l}\text { Pod width, } \\
\text { cm }\end{array}$ & $\begin{array}{l}\text { Weight of } 10 \\
\text { pods, g }\end{array}$ & $\begin{array}{l}\text { Seeds } \\
\text { per pod }\end{array}$ & $\begin{array}{l}\text { 100-seed } \\
\text { weight, g }\end{array}$ \\
\hline ML-01 & 118.0 & 153 & 9.15 & 6.21 & 122.5 & 4.55 & 36.0 \\
\hline ML-02 & 120.5 & 157.5 & 10.65 & 9.11 & 162.5 & 4.5 & 45.6 \\
\hline ML-03 & 116.5 & 153 & 12.55 & 5.72 & 107.5 & 4.1 & 23.5 \\
\hline ML-04 & 116.5 & 156 & 14.3 & 4.5 & 130 & 4.5 & 28.5 \\
\hline ML-05 & 116.5 & 156 & 15.45 & 6.3 & 162.5 & 4.5 & 29.0 \\
\hline ML 07 & 116.5 & 156 & 10.45 & 5.55 & 100 & 3.65 & 34.7 \\
\hline ML-08 & 116.0 & 153 & 14.7 & 4.85 & 130 & 4.85 & 35.1 \\
\hline ML-09 & 81.0 & 140 & 5.35 & 4.92 & 65.0 & 4.15 & 28.1 \\
\hline ML-10 & 117.5 & 152.5 & 6.55 & 4.02 & 45.0 & 4.0 & 18.7 \\
\hline ML-11 & 120.5 & 154.5 & 12.35 & 4.92 & 77.5 & 3.45 & 27.5 \\
\hline ML-15 & 81.0 & 119 & 10.3 & 5.65 & 80.0 & 5.2 & 29.7 \\
\hline ML-16 & 130.0 & 165.5 & 7.0 & 4.35 & 62.5 & 4.1 & 32.7 \\
\hline ML-17 & 124.0 & 163.5 & 10.25 & 4.5 & 105 & 4.7 & 25.0 \\
\hline ML-18 & 117.5 & 159.5 & 13.95 & 5.31 & 110 & 4.4 & 42.0 \\
\hline ML-19 & 120.5 & 163.5 & 13.0 & 3.9 & 75.0 & 5.2 & 28.5 \\
\hline ML-20 & 120.5 & 163.5 & 12.2 & 4.75 & 95.0 & 5.45 & 33.5 \\
\hline ML-21 & 93.5 & 129 & 7.9 & 5.0 & 75.0 & 4.1 & 32.0 \\
\hline ML-22 & 85.5 & 122.5 & 6.45 & 3.98 & 67.5 & 3.6 & 30.0 \\
\hline ML-23 & 107.0 & 163.5 & 10.1 & 5.1 & 70.0 & 4.9 & 37.0 \\
\hline ML-25 & 106.5 & 163.5 & 10.0 & 5.07 & 97.5 & 5.8 & 29.6 \\
\hline ML-26 & 120.5 & 153.5 & 8.45 & 4.05 & 115 & 4.05 & 29.5 \\
\hline ML- 27 & 86.5 & 123.5 & 8.1 & 6.2 & 85.0 & 4.65 & 27.5 \\
\hline ML-28 & 86.5 & 123.5 & 9.05 & 6.55 & 90.0 & 4.05 & 39.0 \\
\hline
\end{tabular}

The maximum weight of 10 fresh pods was recorded in ML-02 and ML-05 (162.5 g) followed by ML-04 and ML-08 (130 g) (Table 4). The minimum weight was recorded in ML-10 (45.0 g) followed by ML-16 (62.5 g) and ML-09 (65.0g). The maximum number of seeds per pod was recorded in ML-25 (6) followed by ML-20 (5). Other genotypes with higher seeds number per pod were ML-15 and ML-19 (5). The minimum seeds number of per pod was recorded in ML-11 (3) followed by ML-07 and ML-22 (4).Great variation was recorded in seed weight which ranged from 18.7 to $45.6 \mathrm{~g} / 100$ seeds). The two yearsmean data showed that the highest 100 -seed weight was recorded in ML-18 (44.0g) followed by ML-02 (41.2g). Other bold grain type genotypes were ML-25 (39.3g), ML-28 (38.0 g) and ML20 (37.0 g). The lowest 100-seed weight was recorded in ML-10 (18.7g).

\section{Cluster Analysis}

Cluster analysis was undertaken to objectively divide the germplasm into natural groups. Clustering was performed on standardized vriables using Euclidean distance for single linkage method.This clustering in natural groups is represented by a dendrogram progressively dividing the accessions into smaller and smaller groups (KC 2001). There were four clusters, among which cluster I consisted of the highest number of genotypes ie 15 genotypes followed by cluster II with 6 genotypes (Figure 1, Table 5). Two genotpe namely ML-10 and ML-02 made separate clustersindvidually, indicating unique features in these two genotypes among the 23 genotypes of lablab beans.

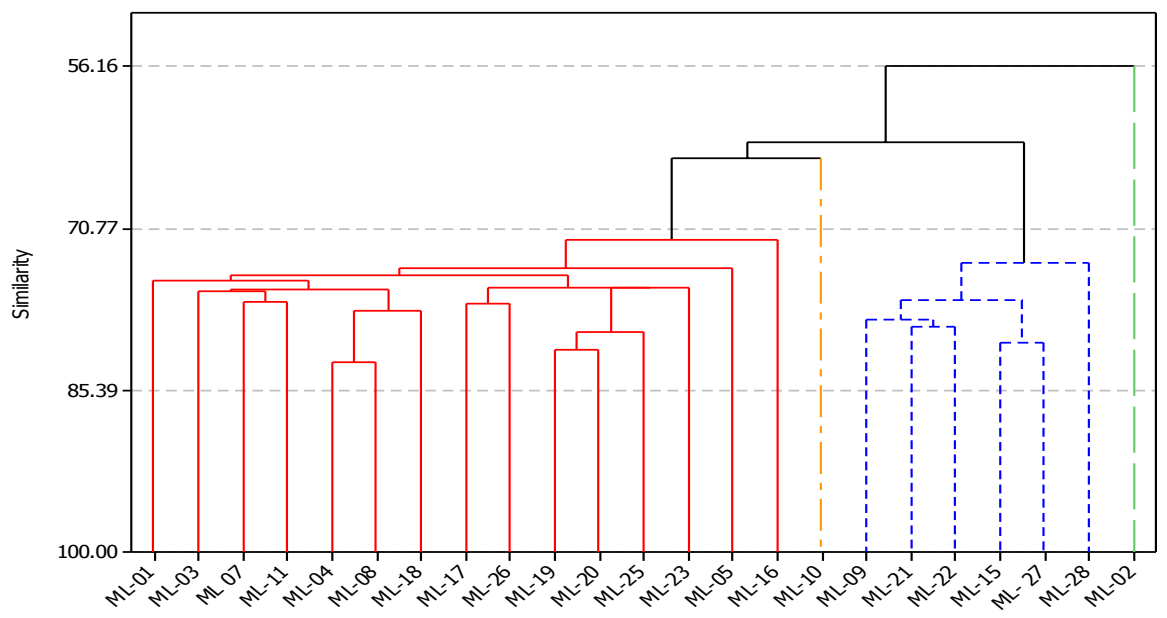

Figure 1. Cluster analysis of 23 accessions of lablab beans collected from different parts of Nepal and characterized over two years in Pokhara, Nepal. 
Vol. 2:15-21, December 2016

DOI: http://dx.doi.org/10.3126/jnarc.v2i0.16116

Table 5. Distribution of 23 genotypes in different clusters based on yield and physico-morphological traits

\begin{tabular}{|l|r|l|r|}
\hline Cluster & $\begin{array}{l}\text { No. } \\
\text { genotype }\end{array}$ & of & Percent \\
\hline I & 15 & $\begin{array}{l}\text { M101, ML03, ML07, ML11, ML04, ML08, ML18, } \\
\text { ML17, ML26, ML19, ML20, ML25, ML23, ML06, } \\
\text { ML16, ML10 }\end{array}$ & 65.22 \\
\hline II & 1 & ML10 & 4.35 \\
\hline III & 6 & ML09, M121, ML22, ML15, ML27, ML28 & 6.26 \\
\hline IV & 1 & ML02 & 4.35 \\
\hline
\end{tabular}

\section{Principal Component Analysis}

The first two principal components with eigen values greater than 1.0 accounted for about $66 \%$ of the variation among the collection (Table 6). Third and forth components accounted for 14 and $9 \%$ of the total variation. Here principal component reduces the dimensionality of multivariate data by removing interrelations among variables and eigen value represents the variance of principal component (Matus 1999). The first principal component (PC1) which explained 39\% variation, was associated mainly with days to $50 \%$ flowering, pod maturity, pod length and pod weight. The second principal component (PC2) was responsible for about $26 \%$ of the variation and was mainly related to pod width and 100 seed weight.

Table 6. Eigen analysis and principal component coefficients based on correlation matrix of six variables measured in 23 lablab bean genotypes evaluated over two years

\begin{tabular}{|l|r|r|r|r|}
\hline Variable & PC1 & PC2 & PC3 & PC4 \\
\hline Eigen value & 2.77 & 1.87 & 0.99 & 0.69 \\
\hline Proportion & 0.396 & 0.267 & 0.142 & 0.099 \\
\hline Cumulative & 0.396 & 0.663 & 0.805 & 0.904 \\
\hline Flowering days & 0.429 & -0.413 & -0.337 & -0.138 \\
\hline Pod maturity first harvest & 0.425 & -0.435 & -0.105 & -0.359 \\
\hline Pod length & 0.473 & -0.053 & 0.190 & 0.529 \\
\hline Pod width & 0.235 & 0.595 & -0.120 & -0.040 \\
\hline 10-pod weight & 0.485 & 0.264 & -0.067 & 0.390 \\
\hline Seeds/pod & 0.217 & -0.030 & 0.897 & -0.265 \\
\hline 100-seed weight & 0.272 & 0.462 & -0.127 & -0.590 \\
\hline
\end{tabular}

The dispersion of the 23 genotypes in Figure 2 showed considerable amount of variability because of collections from different areas. Four distinct groups can also be obsereved based on the principal compoenent analysis. ML-02 is located very far from the center and has positively higher value for most of the traits whereas, ML-10 has relatively small value for most of the triats and located in the third quardrant.

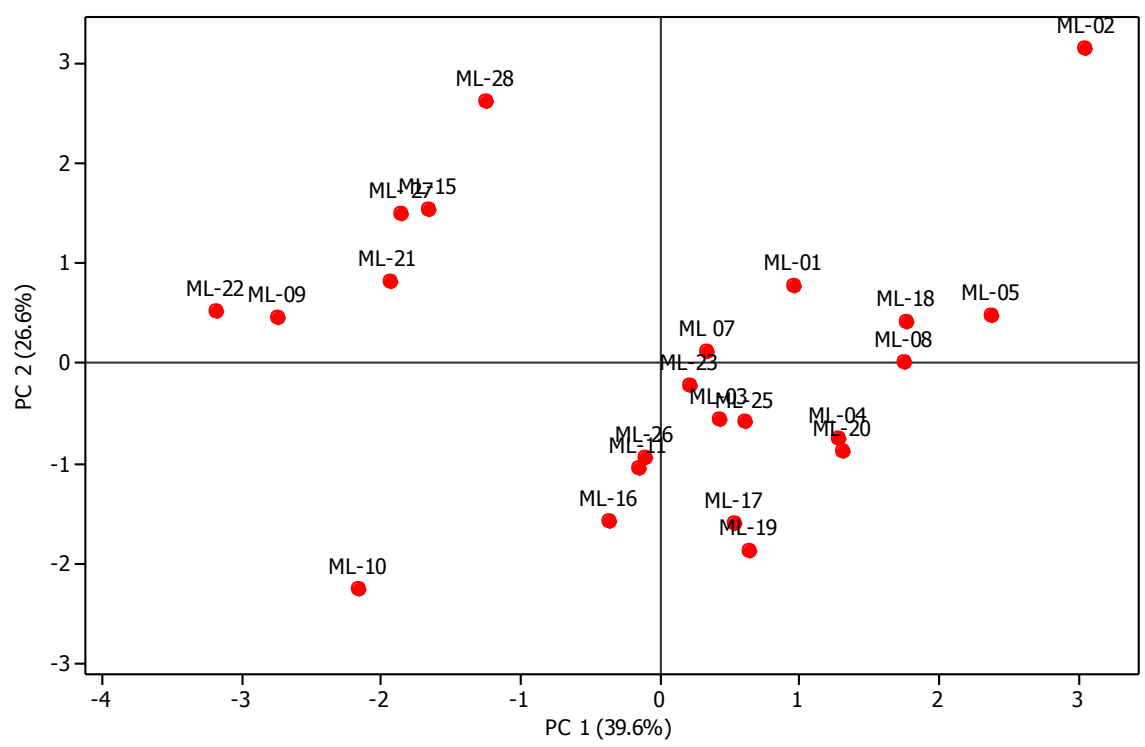

Figure 2. Principal component analysis of 23 accessions of lab lab beans collected from different district of Nepal and characterized over two year in Pokhara, Nepal. 


\section{DISCUSSION}

Germplasm characterization is an important component of breeding program for an effective and efficient management and utilization. Assessment of genetic diaristy is an essential component in germplasm characterization and conservation (Chakravarthi 2006). Morphological markers have been used for assessment of relationships among lab labbean genotypes and for estimating genetic diversity among them (Table 2, 4, Figure 2). The germplasm used in present studies showed a wide variation in morphological traits like number of pods/plant and pod length (Tabe 2, Table 4, Figure 1, Table 6, Figure 2) . The immense genetic diversity of landraces of crops is the most directly useful and economically valuable part of biodiversity. Unlike high yielding varieties, the landraces maintained by farmers are endowed with tremendous genetic variability, as they are not subjected to subtle selection over a long period. Such diversity should be conserved by collecting extensily from the local areas removing duplicates in the collection.

In present findings the colur of vine color we observed was similar to that of Islam (2010) who reported that large portion (43.2\%) were green vine color in Bangladesh. Islam et al (2002) divided stem color in two groups such as green and purple, which was also similar with the present results. Pod color is very important in the market and consumer prefer green pod. More than half of the germplasm have greed pod. Islam (2010) also reported 52.3\% were green color pod in his study.Pod length is directly related to total economic harvest. Priority should therefore be given to ML-05 for further advancing and selecting the genotypes. Variation in pod length was similar to Islam (2010) who reported variation on it from $3.96 \mathrm{~cm}$ to $18.20 \mathrm{~cm}$.

The plant has many outstanding qualities. It is tolerant of high-temperatures and drought, can thrive in deep sands to heavy clays and produces a large bulk of green material with high protein concentration (Kay 1979). These qualities enable the plant to provide food, fodder and soil protection during prolonged dry periods when many other plant species have become desiccated (Schaaffhausen 1963, Wood 1983).Lablab is better adapted to drought than common beans (Phaseolus vulgaris) or cowpea (Vignaunguiculata). Variation therefore observed in these genotypes can be very important soruces for developing site specific variety targeting drought areas eg western Nepal.

We observed diversity in farmers' preferred traits based on the assessment of genetic diversity using phenotype. The information generated here may have limitations, since most of the morphological characters are greatly influenced by environmental factors and the development stage of the plant. Further diversity assessment is recommended using DNA markers.

Results obtained from this study are very useful to enhance the genetic management and improvement of this multipurpose crop species particularly to develop high yielding variety. The narrow genetic base for breeding stocks may be increased including these genotypes. Extensive exchange of germplasm among smallholder farmers across the country may dilute the existing diversity. The identified genetically distinct genotypes could be potentially important source for further improvement of lab labbean.

\section{CONCLUSION}

The evaluated germplasm showed significant variations in most of the qualitative and quantitative traits. Variation was observed in both phenological and yield attributing characters. Simple location specific evaluation and selection may be sufficient to develop high yielding, early type varieties from these gentopypes.

\section{ACKNOWLDGEMENT}

Nepal Agriculture Research Council is highly acknowledged for funding. Appreciation to all those farmers who share their valuable germplasm of lablab beans without any cost.

\section{REFRENCESS}

ARS. 2013. Annual Report 2012. Agriculture Research Station, NARC, Malepatan, Pokhara.

ARS. 2014. Annual Report 2013. Agriculture Research Station, NARC, Malepatan, Pokhara.

Chadha KL. 2001. Hand book of agriculture. Indian Council of Agricultural Research, New Delhi.

Chakravarthi BK and R Naravaneni. 2006. SSR marker based DNA finger printing and diversity in rice (Oryza sativa L.) African Journal of Biotechnology 5(9):684-688.

Genebank. 2014. Annual Report 207071 (2013/14). National Agriculture Genetic Resources Center (Genebank).BK Joshi, KH Ghimire and D Singh, eds. Khumaltar.

Islam MDN, MZ Rahman, R Ali, AK Azad and MK Sultan. 2014. Diversity analysis and establishment of core subsets of hyacinth bean collection of Bangladesh. Pakistan J. Agric. Res. 27(2):99-109.

Islam MS, MMRahaman and T Hossain. 2010. Physico-morphological variation in hyacinth bean (Lablab purpureusL.) Bangladesh J. Agri. Res. 35(3):431-438.

Islam MT. 2008.Morpho-agronomic diversity of hyacinth bean (Lablab purpureus (L.)Sweet) accessions from Bangladesh. Plant Genetic Resources Newsletter 156:73-78.

Islam T, MM Haque and MM Rahman. 2002. Catalogue in hyacinth bean germplasm PGRC, BARI, Gazipur, p.55.

Joshi BK, K Okuno, R Ohsawa and HP Bimb. 2010. Principal component and cluster analyses of Nepalese Tartary buckwheat diversity. Fagopyrum 27:55-66.

Kay DE. 1979. Crop and Product Digest No 3- Food legumes. Tropical Products Institute, London.

KC RB, MD Sharma, D Panthee and DM Gautam. 2001. Physio-morphological chatecterization of indegenious garlic germplasm of Nepal. Master Thesis. Institute of Agriculture and Animal Science Rampur, Nepal.

Kimani EN, FN Wachira and MG Kinyua. 2012. Molecular diversity of Kenyan Lablab bean (Lablab purpureus (L.) Sweet) accessions using Amplified Fragment Length Polymorphism markers. American Journal of Plant Sciences 3:313-321. 
Liu CJ. 1996. Genetic diversity and relationships among Lablab purpureus genotypes evaluated using RAPD as markers. Euphytica 90:115-119. Maass BL, MR Knox, SC Venkatesha, TTAngessa, S Ramme and BC Pengelly. 2010. Lablab purpureus- a crop lost for Africa? Trop. Plant. Biol. 3(3):123-135

Matus I, MI Gonzalez and A del Pozo.1999. Evaluation of phenotypic variation in a Chilean collection of garlic clones using multivariate analysis. Plant genetic resources Newsletter 117:31-36.

NagendraRai N, PK Singh, AC Rai, VP Rai and M Singh. 2011. Genetic diversity in Indian bean (Lablab purpureus) germplasm based on morphological traits and RAPD markers. Indian Journal of Agricultural Sciences 81(9):801-806.

Rai N, A Kumar, PK Singh, M Singh, D Datta and M Rai. 2010. Genetic relationship among Hyacinth bean (Lablab purpureus) genotypes cultivars from different races based on quantitative traits and random amplified polymorphic DNA marker. African Journal of Biotechnology 9(2):137-144.

Schaafthausen RV. 1963. Dolichos lablab or Hyacinth bean: Its uses for feed, food and soil improvement. Economic Botany 17:146-153.

Sultana N. 2001.Genetic variation of morphology and molecular markers and its application to breeding in lablab bean.PhD Thesis, Kyushu University, Fikuoka, Japan.

Wood IM. 1983. Lablab bean (Lablab purpureus) for grain and forage production in the Ord Irrigation Area. Aust. J. Exp. Agric. Anim. Hush. 23:162-171. 